\title{
Discovery of an apostome ciliate (Collinia beringensis n. sp.) endoparasitic in the Bering Sea euphausiid Thysanoessa inermis
}

\author{
Gerard M. Capriulo ${ }^{1}$ \& Eugene B. Small ${ }^{2}$ \\ ${ }^{1}$ Division of Natural Sciences, State University of New York at Purchase, New York 10577, USA \\ ${ }^{2}$ Department of Zoology, University of Maryland at College Park, Maryland 20742, USA
}

\begin{abstract}
The discovery is reported of a species of apostome ciliate, Collinia beringensis, n. sp., living endoparasitically in the haemocoel cavity of the Bering Sea euphausiid Thysanoessa inermis. This ciliate bears a falciform field and rosette structure in the protomite 2 stage and has a y (but not the full $x, y, z$ ) kinetid arrangement. Trophont, tomont, protomite 1 and tomitogenesis stages were also observed. The tomont, trophont and protomite 1 stages are characterized by an astomatous condition, and a denuded field was observed in the tomont and protomite 1 stages.
\end{abstract}

\section{INTRODUCTION}

Euphausiids occur in vast numbers, represent a significant proportion of the biomass of the oceans of the world and are an important and often major food source for many marine animals including whales, fish, seals, and birds (Mauchline \& Fisher 1969). Several species of euphausids including Meganyctiphanes norvegica (Sars), Thysanoessa inermis (Kroyer) and, at times, T. raschii (Sars), occur in extremely high densities in northern seas, as do related species in Antarctic waters.

The importance of Euphausia superba Dana to baleen whales has been demonstrated (Marr 1962). The significance of several euphausiid species as food for a variety of fish including hake (Hickling 1927), herring and mackerel (Mauchline \& Fisher 1969) and fish of the Skagerrak, has also been pointed out. The euphausiids Meganyctiphanes norvegica and Thysanoessa inermis have been shown to be main food items for whales of the northern seas (Hjort \& Ruud 1929). The significance of krill as food for whales arises not from high numbers alone, but also from their swarming behavior, which results in patches of high concentration which can be detected by their predators.

In view of the importance of euphausiids to pelagic food webs, it is of obvious value to understand various phenomena which might affect the growth, reproduction and general well-being of euphausid populations.

\section{Euphausiid parasites}

A review of the parasites of euphausiids can be found in Mauchline (1980). Three types of ectoparasites are found and include: ellobiopsids, dajid isopods and apostome ciliates (Table 24 of Mauchline 1980). The ellobiopsids have been classed as fungi, dinoflagellates or rhizopod Protozoa (Mauchline \& Fisher 1969). Certain of these parasites affect host development, for example Notophryxus lateralis (which parasitizes Nematoscelis difficilis in the Santa Barbara Channel, California) and Thalassomyces fagei may inhibit moulting in their host euphausiids (Field 1969). Apostome ciliate resting cysts have been reported attached to various krill species such as Meganyctiphanes norvegica, Nyctiphanes couchi, Euphausia hemigibba, E. krohni, Thysanoessa gregaria, T. inermis, T. longicaudata, T. raschi and Nematoscelis megalops in the North Atlantic (Lindley 1978). Infection ranges from 3 to $16 \%$ of the population. Lindley described the geographical distribution of infected euphausiids and concluded that neritic species and populations are more liable to infection than offshore oceanic species and populations. 
The known endoparasites of euphausids have also been described by Mauchline (1980). Euphausiids are the intermediate host of certain nematodes (species of Anisakis; Komaki 1970). Oshima (1969) experimentally infected Euphausia pacifica and E. similis with Anisakis larvae, and also Shimazu \& Oshima (1972) demonstrated natural infection of North Pacific euphausiids by Anisakis larvae. Parasites have also been found in Barents Sea Thysanoessa raschii (Uspenskaya 1963), North Sea Thysanoessa species

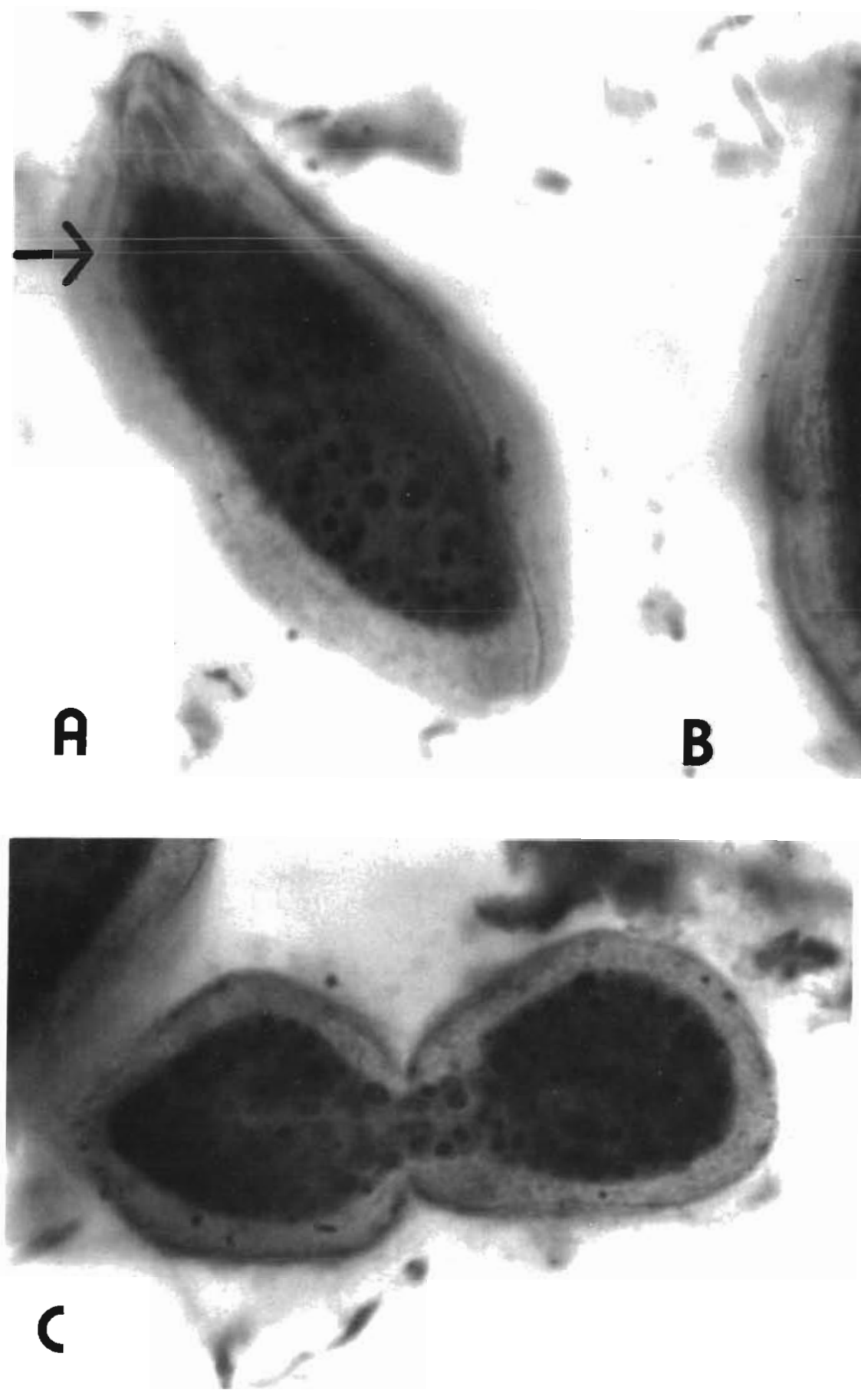

(Smith 1971, Lindley 1977) as well as in other euphausid species (Shimazu \& Oshima 1972). Parasitic trematodes (Sars 1885, Komaki 1970, Shimazu \& Kagei 1978), cestodes (Shimazu 1975) and acathocephalan larvae (Sars 1885, Shimazu 1975, Lindley 1977) have also been reported for euphausiids.

None of the above works note the occurrence of an endoparasitic ciliate in any species of euphausiid. We here describe a prevously unknown apostome ciliate endoparasite of the euphausiid Thysanoessa inermis.

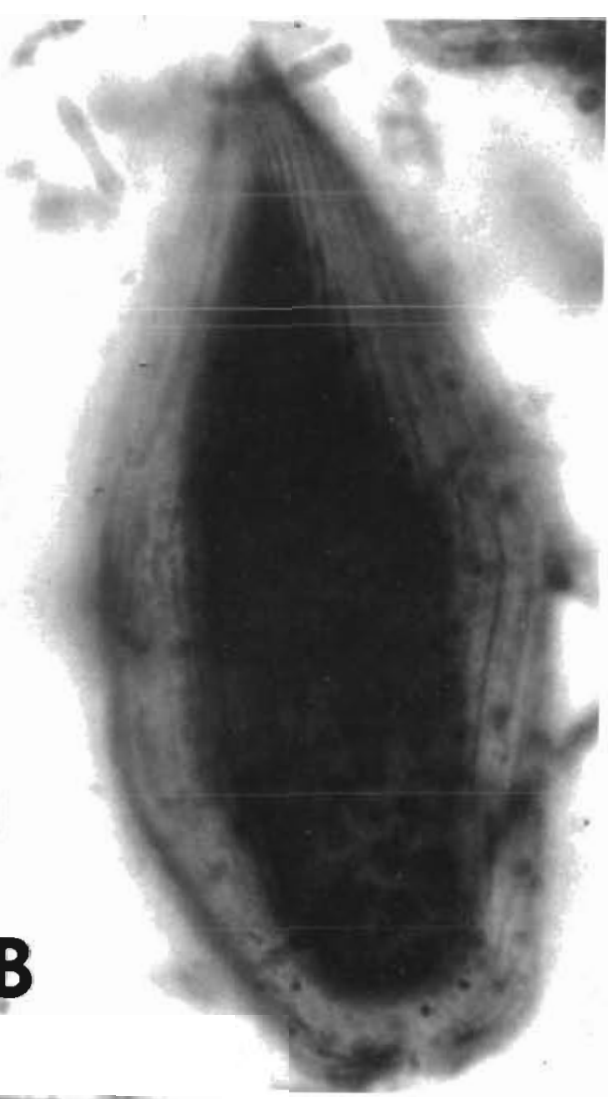

Fig. 1. Collinea beringensis. Light micrographs including (A) the protomite 2 stage with rosette structure (arrow), (B) the tomont stage and (C) tomitogenesis (cell division) 


\section{Apostomatid ciliates}

This group of parasites is characterized in Corliss (1979) and Small \& Lynn (1985). The apostomes are associated with marine and fresh water crustaceans, cephalopods, ophiurans, coelenterates, ctenophores, polychaete annelids and possibly edaphic (terrestrial) acari. The best known species are commonly found in marine crustacean hosts such as hermit crabs and copepods. Those with 2 known hosts have sea anemones as the second. Those forms found on fresh and salt water invertebrates, such as the crustaceans including krill, are ectoparasitic forms (as are most apostomes) which excyst at the time when their host ecdyses, whereupon the excysted ciliate goes through a polymorphic life history in which nourishment is derived from the exuvial fluid of the ecdysed exoskeleton (Corliss 1979). Freshwater hosts include shrimp (Miyashita 1933) and gammarids (Penard 1922). FaureFremiet \& Mugard (1949) described as an apostome Cyrtocaryum sp., occurring in annelids, but according to Corliss (1979) this genus is not representative of the group. Several papers on host-parasite relations concerning the apostomes can be found (Puytorac 1953, Debaisieux 1957, 1969, Trager 1957, Puytorac \& Lom 1962, Fenchel 1965, Jakschnik 1967, Jankowski 1967 , Grimes 1976, Lindley 1978), none of which described apostomes endoparasitic in krill.

Apostome are characterized as possessing an inconspicuous cytostome or no cytostome, an organelle which when present is often accompanied by a unique rosette structure (Corliss 1979), and as exhibiting a complex polymorphic life cycle involving an orderly succession of distinguished stages (phoront, trophont, protomont, tomont, protomite, tomite) some of which are depicted in Fig. $1 \& 2$. The structure of the cytostome-cytopharyngeal rosette has not been completely resolved, although Bradbury (1966a, b, 1973) has done much to describe the structure. Apostome life cycles have been described by Chatton \& Lwoff (1935), Kirby (1941), Lwoff (1950) and Bradbury (1966a) and certain kinetal segments or fields have been found to be strongly thigmotactic. Collin (1909) described conjugation in the apostome Collinia branchiarum (Stein). Chatton \& Lwoff (1930) wrote an extensive monograph on the systematics of the apostomes as known to that date.

In addition to the references cited above, several other works by Bradbury and her associates have done much to enhance our understanding of this group of ciliates (Bradbury \& Pitelka 1965, Bradbury \& Trager 1967a, b, Bradbury \& Clamp 1973, Bradbury 1974 , 1975, Bradbury et al. 1974, Bradbury \& Goyal 1976, Johnson \& Bradbury 1976).

Endoparasitic apostomes have been noted in crustaceans such as Orchestia gammarella (Puytorac \& Grain 1975); Gammarus pulex (Puytorac 1953) freshwater isopods of the genus Asellus (Balbiani 1885), as well as in other crustaceans (Puytorac \& Lom 1962). Collin (1909) found endoparasitic apostomes in amphipods and speculated that transfer occurred when the amphipods were injured by attacks from other amphipods. In general apostomes belonging to the family Colliniidae are usually found as parasites in the body cavity fluids of fresh-water crustaceans (i.e. Gammarus, Asellus and Neóniphargus). The new
Fig. 2. Collinea beringensis. Line drawings of the 5 observed stages of development with the rosette structure (R), flaciform field $(F)$ and $y$ kinetid arrangement ( $Y$ ) seen in the protomite 2 stage; and the denuded somatic region seen in the tomont and protomite 1 stages. 'Ratio' = length to width ratio of the particular stage. The overtly large macronucleus present in all observed stages is shown with the noted nucleoli in the trophont and tomitogenesis (cell division) stages. As depicted in the division stage, elongate nucleoli were observed

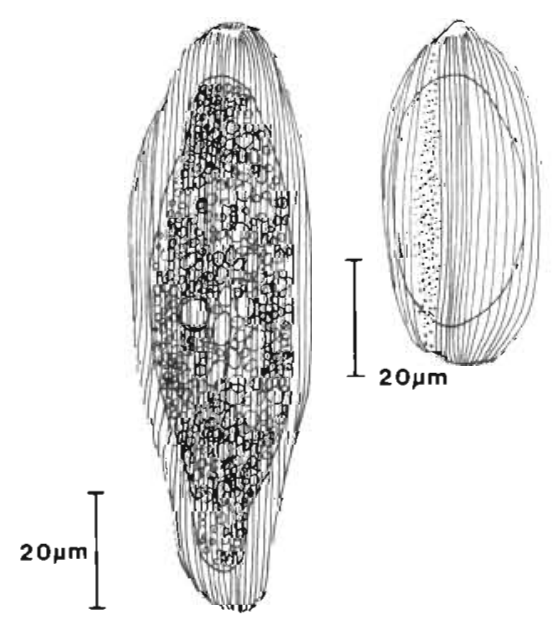

BODY

$90 \mu \mathrm{m} \times 30 \mu \mathrm{m} 58 \mu \mathrm{m} \times 25 \mu \mathrm{m}$
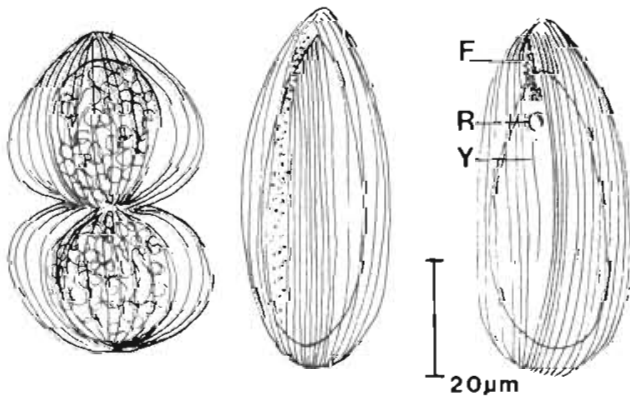

MACRONUCLEUS $75 \mu \mathrm{m} \times 25 \mu \mathrm{m} 42 \mu \mathrm{m} \times 21 \mu \mathrm{m}$

RATIO

KINETIES
$3: 1$

80

TROPHONT
2.3:1

34

TOMONT
30

OBSERVED
$47 \mu \mathrm{m} \times 26 \mu \mathrm{m}$

$42 \mu \mathrm{m} \times 18 \mu \mathrm{m}$

1.8:1

28

PROTOMITE 1
$45 \mu \mathrm{m} \times 28 \mu \mathrm{m}$

$36 \mu \mathrm{m} \times 20 \mu \mathrm{m}$

1.6: 1

24
PROTOMITE 2 
species herein described in our view belongs to the family Colliniidae and extends the host list to include the marine krill species Thysanoessa inermis.

\section{MATERIALS AND METHODS}

The euphausiids examined in this study were collected both by means of multiple opening closing net (MOCNES) tows and oblique, $1 \mathrm{~mm}$ mesh, plankton net tows. Samples were collected by Dr. Sharon Smith and Mr Dominick Ninivaggi as part of the Brookhaven National Laboratories' involvement in the National Science Foundation funded PROBES project. Samples were taken from the entire water column at several stations in the Bering Sea, and were fixed in $10 \%$ buffered formalin.

Some of the above samples were transferred to Bouin's fixative (see Small's procedure in Lee et al. 1985) which is a saturated solution of picric acid in $\mathrm{CaCo}_{3}$ buffered formaldehyde plus $1 \% \mathrm{v} / \mathrm{v}$ glacial acetic acid added at the time of dilution in a 20:1 seawater to fixative ratio. Stomach and intestinal sections of some of the Thysanoessa inermis individuals were dissected out and prepared, along with entire organisms, for protargol silver staining following the procedure of Small as presented in Lee et al. (1985). The purpose of the stain was to facilitate examination for the potential presence of ciliate food items.

\section{RESULTS}

Examination of the stained intestines of Thysanoessa inermis revealed cysts possibly belonging to a ciliate. Follow-up examination of 50 other euphausiids, pre- served either in formalin or Boun's fixative, revealed 5 individuals with a haemocoel cavity that appeared to be 'cloudy' or opaque white. These individuals were carefully opened and found to be densely packed with ciliates. The ciliates were removed and stained with protargol (Fig. 1). It can be noted that $T$. inermis with opaque white haemocoels may be filled with ciliates, although larger sample sizes are still needed to fully confirm this correlation. The ciliates were found to completely fill the haemocoel cavity of the infected individuals examined.

This endoparasitic ciliate is an apostome which bears a falciform field and rosette structure in the protomite 2 stage as well as a $y$ (but not the full $x, y, z$ ) kinetid arrangement (Fig. 1A \& 2). Trophont, tomont and protomite 1 stages were also observed (Fig. 2) as was tomitogenesis (Fig. 2, observed division; Fig. 1C). The observed number of kineties varies from 24 to 80 (Fig. 2, Table 1) and the tomont, trophont and protomite 1 stages are characterized by an astomatous (no mouth) condition with the tomont and protomite 1 stages additionally characterized by a denuded somatic region.

\section{DISCUSSION}

This parasitic apostome, in our opinion, most closely resembles other known species in the genus Collinia in the family Colliniidae (Tables $1 \& 2$ ).

The following similarities exist between the krill apostome and other described Collinia spp.: (1) presence of rosette structure and special kinetal y segment; (2) haemocoel dwelling forms in crustaceans; (3) all are forms whose complete life history is unknown; (4) major stages in which the mechanism of food ingestion is pinocytosis rather than phagocytosis; (5) are

Table 1. Collinia spp. Life history stage comparisons

\begin{tabular}{|c|c|c|c|c|c|c|}
\hline \multirow[b]{2}{*}{ Species and host } & \multicolumn{6}{|c|}{ Cell cycle stage with respective length/width measurements and number of kineties } \\
\hline & Trophont & Tomont & Protomite 1 & Protomite 2 & Tomite 1 & Tomite 2 \\
\hline C. branchiarum (Stein) & \multicolumn{6}{|l|}{$100 \times 80 \mu \mathrm{m}$} \\
\hline Host: Gammarus pulex & \multirow{2}{*}{\multicolumn{2}{|c|}{ ab - Astomatous- }} & 34 & 9 & $?$ & $?$ \\
\hline Rosette $+x, y, z$ & & & & -Apostomatous & & \multirow{4}{*}{$\begin{array}{c}10 \times 6 \mu \mathrm{m} \\
10 \\
\text { Astomatous }\end{array}$} \\
\hline - Collinia sp.; n. sp. & $90 \times 80 \mu \mathrm{m}$ & $65 \times 25 \mu \mathrm{m}$ & $35 \times 25 \mu \mathrm{m}$ & $20 \times 15 \mu \mathrm{m}$ & $18 \times 10 \mu \mathrm{m}$ & \\
\hline \multirow[t]{2}{*}{ Host: Bactrurus mucronatus } & 40 & 16 & 14 & 12 & 11 & \\
\hline & \multicolumn{2}{|c|}{ - Astomatous } & & $\begin{array}{l}\text { Division and } \\
\text { conjugation } \\
\text { noted }\end{array}$ & $\begin{array}{l}\text { Division and } \\
\text { conjugation } \\
\text { noted }\end{array}$ & \\
\hline C. beringensis n. sp. & $90 \times 30 \mu \mathrm{m}$ & $58 \times 25 \mu \mathrm{m}$ & $47 \times 26 \mu \Pi$ & $45 \times 28 \mu \mathrm{m}$ & Not ob & ved \\
\hline $\begin{array}{l}\text { Host: Thysanoessa inermis } \\
\text { Rosette }+y(\text { no } x, z)\end{array}$ & 80 & $\begin{array}{c}34 \\
\text { Astomatous- }\end{array}$ & 28 & $\begin{array}{c}24 \\
\text { Apostomatous }\end{array}$ & $?$ & $?$ \\
\hline
\end{tabular}


Table 2. Known species of the genus Collinia with respective hosts, host distribution and geographic localities

\begin{tabular}{|lll|}
\hline Species & Host & Geographic localities \\
\hline $\begin{array}{l}\text { 1. C. branchiarum (Stein 1852) } \\
\text { synonyms: Opalina branchiarum (Stein 1852) } \\
\text { Anaplophrya branchiarum }\end{array}$ & $\begin{array}{l}\text { Gammarus pulex: } \\
\text { freshwater amphipod, } \\
\text { epigean }\end{array}$ & $\begin{array}{l}\text { Germany, freshwater } \\
\text { England, freshwater } \\
\text { France, freshwater } \\
\text { Czechoslovakia, freshwater }\end{array}$ \\
$\begin{array}{ll}\text { 2. C. circulans (Balbiani 1885) } \\
\text { syn. A. circulans (Balbiani) Schneider 1885 }\end{array}$ & $\begin{array}{l}\text { Asellus aquatiaus: } \\
\text { freshwater isopod, } \\
\text { epigean }\end{array}$ & $\begin{array}{l}\text { France, freshwater } \\
\text { Germany, freshwater }\end{array}$ \\
3. C. neopharqi (Cepede 1910) & $\begin{array}{l}\text { Neoniphargus moniezi: } \\
\text { Oreshwater, subterranean }\end{array}$ & France, freshwater \\
4. C. orchestiae (Summers \& Kidder) & $\begin{array}{l}\text { marine sandy beaches } \\
\text { Pallasea cancelloides }\end{array}$ & USA, Woods Hole marine beach \\
5. C. gammari (Cheissin 1930) & $\begin{array}{l}\text { Echinogammarus Maaki } \\
\text { Bactrurus mucronatus: }\end{array}$ & USSR, Lake Baikal \\
6. C. sp. (an unpublished species, Small) & freshwater, subterranean & USA, Illinois drainage tiles \\
\end{tabular}

forms which appear to be functional astomes with minimal apostome traits for the life history stages known at this time.

Since trophic forms of this krill apostome are astomatous and haemocoel dwelling, and because they so resemble Anoplophrya, a true astome, perhaps the other haemocoel-dwelling Anoplophrya-like astomes are also apostomes with arrested polymorphic life histories.

Each krill host examined contained thousands of apostome ciliates. The packing of these ciliates was so tight that each cell had an irregular shape apparently determined by the degree of packing in the host at its respective location. Such parasite densities as observed here suggest that impairment of normal physiological functioning (as well as possible death) of the host may be occurring.

The mechanism by which this ciliate endoparasite infects its host is puzzling since the euphausiid haemocoel cavity is enclosed at all times during its development. Possibly, transfer of the parasite into the euphausiid occurs at predator-inflicted injury sites as was suggested by Collin (1909) with regard to a ciliate endoparasite found in an amphipod.

At the present time we do not have informaton on the extent of parasitism of the Bering Sea euphausidd Thysanoessa inermis, how infestation varies temporally or spatially, nor what the likelihood is that other euphausiids of the region, and perhaps even other crustaceans such as copepods, are also parasitized by this ciliate. Also, we have not as yet determined which organs might be affected. Such information is obviously essential to an understanding of the ciliate's ecology and what affect the ciliates might have on the host's physiology.

Acknowledgements: We thank Dr. Sharon Smith and Dominick Ninivaggi for providing us with the euphausiid samples. This research was made possible in part by a grant from the Hudson River Foundation for Science and Environmental Research (to GMC) and NSF Grant DPP-76-23340 (to SS).

\section{LITERATURE CITED}

Balbiani, E. G. (1885). Sur un infusoire cilie parasite du sang de l'aselle aquatique (Anoplophrya circulans). Zool. Suisse 2: 277-305

Bradbury, P. C. (1966a). The life cycle and morphology of the apostomatous ciliate, Hyalophysa chattoni ng, ns. J. Protozool. 13: 209-225

Bradbury, P. C. (1966b). The fine structure of the mature tomite of Hyalophysa chattoni. J. Protozool. 13: 591-607

Bradbury, P. C. (1973). The fine structure of the cytostome of the apostomatous ciliate Hyalophysa chattoni. J. Protozool. 20: 405-414

Bradbury, P. C. (1974). The fine structure of the phoront of the apostomatous ciliate Hyalophysa chattoni. J. Protozool. 21: $112-120$

Bradbury, P. C. (1975). Stored membranes associated with feeding in apostome trophonts with different diets. Protistologica 10: 533-542

Bradbury, P. C., Clamp, J. C. (1973). Hyalophysa Iwoffi sp. n. from the fresh water shrimp Palaemonetes paludosus and revision of the genus Hyalophysa. J. Protozool. 20: 210-213

Bradbury, P. C., Goyal, V. (1976). The fine structure of a parasitic ciliate Terebrospira during ingestion of the exoskeleton of a shrimp Palaemonetes. Tissue Cell 8: 573-582

Bradbury, P. C., Pitelka, D. R. (1965). Observations on kinetosome formation in an apostome ciliate. J. Micros. (Paris) 4 : $805-810$

Bradbury, P. C., Trager, W. (1967a). Excystation of apostome of Hyalophysa chattoni. J. Protozool. 13: 591-607

Bradbury, P. C., Trager, W. (1967b). Excystation of apostome ciliates in relation to molting of their crustacean hosts. II. Effect of glycogen. Biol. Bull. mar. biol. Lab., Woods Hole 133: $310-316$

Bradbury, P. C., Clamp, J. C., Lyon, J. (1974). Terebrospira chattoni sp. n. a parasite of the endocuticle of the shrimp Palaemonetes pugio Holthius. J. Protozool. 21: 678:686

Chatton, E., Lwoff, A. (1930). Impregnation par diffusion argentique de l'infraciliature des cilies marin et d'eau 
douce, après fixation cytologique et sans dessication. C. r. Séanc. Soc. Biol. 104: 834-836

Chatton, E., Lwoff, A. (1935), Les cilies apostomes. Morphologie, cytologie, ethologie, evolution, systematique. Première partie. Aperçu historique et general. Étude monographique des genres et des espèces. Archs Zool. exp. gen. 77: 1-453

Collin, B. (1909). La conjugaison d'Anoplophrya branchiarium. Archs Zool. Paris (ser. 5) 1: 325-388

Corliss, J. O. (1979). The ciliated Prototoa: characteristics, classification and guide to the literature. 2nd edn. Pergamon Press, Oxford

Debaisieux, P. (1957). Foettingeride a migration transcuticulaire. Bull. Acad. r. Belg. Cl. Sci. (ser. 5) 43: 98-105

Debaisieux, P. (1960). Ciliate apostomes parasites de palaemon. Cellule 60: 331-352

Faure-Fremiet, E., Mugard, H. (1949). Un infusoire apostome parasite d'un polychete: Cyrtocaryum halosydnae, n. g. n. sp. C. r. hebd. Seanc. Acad. Sci., Paris 228: 1753-1755

Fenchel, T. (1965). On the ciliate fauna associated with the marine species of the amphipod genus Gammarus. Ophelia 2: 251-303

Field, L. H. (1969). The biology of Notophryxus lateralis (Isopoda: Epicaridea), parasite on the euphausid Nematoscelis difficilis. J. Parasit. 55: 1271-1277

Grimes, B. H. (1976). Notes on the distribution of Hyalophysa and Gymnodinioides on crustacean hosts in coastal N. Carolina and a description of Hyalophysa trageri sp. n. J. Protozool. 23: 246-251

Hickling, C. F. (1927). The natural history of the hake. Fishery Invest., Lond. Ser. II, 10: 1-100

Hjort, J., Ruud, J. T. (1929). Whaling and fishing in the North Atlantic. Rapp. P.-v. Réun. Cons. perm. int. Explor. Mer. 56: 5-123

Jakschnik, H. D. (1967). Distribution of the ciliate fauna associated with the subterranean fresh-water amphipod, Bactrurus mucronatus (Forbes) Hay. M. S. thesis, Univ. of Illinois

Jankowski, A. W. (1967). Ciliates from the mantle cavity of Balanus in Barents Sea. Parazitologia 1: 82-93

Johnson, C. A. III, Bradbury, P. C. (1976). Observations on the ocuurrence of the parasitic ciliate Synophrya in decapods in coastal waters off the southeastern United States. J. Protozool. 23: 252-256

Kirby, H. (1941). Relationships between certain Protozoa and other animals. In: Calkins, G. N., Summers, F. M. (ed.) Protozoa in biological research. Columbia Univ. Press, New York, p. 899-1008

Komaki, Y. (1970). On the parasitic organisms in a krill, Euphausia similis, from Suruga Bay. J. oceanogr. Soc. Japan 26: 283-295

Lee, J. J., Small, E. B., Lynn, D. H., Bovee, E. C. (1985). Some techniques for collecting, cultivating and observing Protozoa. In: Lee, J. J., Hutner, S. H., Bovee, E. C. (ed.) An illustrated guide to the Protozoa. Allen Press and Soc. of Protozoologists, Kansas, p. 4-5

Lindley, J. A. (1977). Continuous plankton records: the distribution of the Euphausiacea (Crustacea: Malacostraca) in the north Atlantic and the North Sea 1966-1967. J. Biogeograph. 4: 121-133

Lindley, J. A. (1978). Continuous plankton records: the occurrence of apostome ciliates (Protozoa) on Euphausiacea in the North Atlantic Ocean and North Sea. Mar. Biol. 46: 131-136
Lwoff, A. (1950). Problems of morphogenesis in ciliates. Wiley \& Sons, New York

Marr, J. W. S. (1962). The natural history and geography of the antarctic krill (Euphausia superba Dana). 'Discovery' Rep. 32: $33-464$

Mauchline, J., Fisher, L. R. (1969). The biology of euphausiids. In: Russell, F. S., Yonge, M. (ed.) Advances in marine biology Vol. 7. Academic Press, London, p. $1-454$

Mauchline, J. (1980). The biology of mysids and euphausiids. In: Blaxter, J. H. S., Russell, F. S., Yonge, M. (ed.) Advances in marine biology Vol. 18. Academic Press, London p. 1-681

Miyashita, Y. (1933). Studies on a freshwater foettingeriid ciliate, Hyalospira caridinae n. g. n. sp. Jap. J. Zool. 4: 439

Oshima, T. (1969). A study of the first host of Anisakis. Saishin-Igaku 24: 401-404. Fish. Res. Bd Can. Trans. No. $1325,1-12$

Penard, E. (1922). Études sur les infusoires d'eau douce. Georg. and Cie, Geneve

Puytorac, P. de. (1953). Anoplophrya branchiarum (Stein), cilie sanguicole de Gammarus pulex, n'est pas un astone, mais un apostome. C. r. hebd. Séance. Acad Sci., Paris 237: $1787-1789$

Puytorac, P. de, Lom, J. (1962). La tomitogenesis des Collinia cilies apostomes sanguicoles endoparasites des crustaces. Ann. Parasit. Hum. et Comp. 37 (3): 195-209

Puytorac, P. de, Grain, J. (1975). Étude de la tomitogenese et des le ultrastructure des Collinia orchestiae ciliae apostome sanguicoloe endoparasite du crustace Orchestiae gammarella Pallas. Protistologica 8: 61-64

Sars, G. O. (1885). Report on the Schizopoda collected by H. M. S. Challenger during the years 1873-1876. The Voyage of H. M. S. Challenger 13 (37): 158-161

Schauer, R. V. (1972). Excystation of the apostomatous ciliate Halophysa chattoni, without metamorphosis. Biol. Bull. mar. biol. Lab., Woods Hole 143: 215-221

Shimazu, T., Oshima, T. (1972). Some larval nematodes from euphausid crustaceans. In: Takenouti, A. Y. et al. (ed.) Biological oceanography of the northern North Pacific Ocean. Idemitsui Shoten, Tokyo, p. 403-409

Shimazu, T. (1975). Some cestode and acanthocephalan larvae from euphausiid crustaceans collected in the northern North Pacific Ocena. Bull. Jap. Soc. scient. Fish. 41: 813-821

Shimazu, T., Kagei, N. (1978). A metacercaria of the genus Paronatrema (Trematoda: Syncoelliidae) parasitic in Euphausia pacifica (Crustacea: Euphausidae) from the East China Sea. Zool. Mag., Tokyo 87: 158-161

Small, E. B., Lynn, D. (1985). The phylum Ciliophora Doflein. In: Lee, J. J., Hutner, S. H., Bovee, E. C. (ed.) An illustrated guide to the Protozoa. Allen Press and Soc. of Protozoologists, Kansas

Smith, J. W. (1971). Thysanoessa inermis and. T. longicaudata (Euphausiidae) as first intermediate hosts of Anisakis sp. (Nematoda: Ascaridata) in the northern North Sea, to the North of Scotland and Farore. Nature, Lond. 234: 478

Trager, W. (1957). Excystation of apostome ciliates in relation to molting of their crustacean hosts. Biol. Bull. mar. biol. Lab., Woods Hole 112: 132-136

Uspenskaya, A. V. (1963). Parasite-Fauna of benthic crustaceans in the Barents Sea. Murmanskii Morskoii Biologischeskii Institut. Akademia Nauk, SSSR, Moscow 